\title{
DISPARITAS EFISIENSI TEKNIS ANTAR SUB SEKTOR DALAM INDUSTRI MANUFAKTUR DI INDONESIA, APLIKASI DATA ENVELOPMENT ANALYSIS
}

\author{
Etty Puji Lestari (ettyplt@yahoo.com) \\ Universitas Diponegoro
}

\begin{abstract}
Efficiency is a parameter to measure performance quality of a company or agency, including manufacture industrial. One of tools was used to measure technical efficiency is Data Envelopment Analysis (DEA). This article attempts to investigate the existence of difference technical efficiency between sub sector in manufacture industry in Indonesia period 19902002 using DEA. This estimation result discovered that the generally performance of manufacture sector industrial in Indonesia growth in spanning perception 1990 and 2002 relative stabilize altought have decrease percentage of efficiency in economic crisis. On the contrary, these conditions do not followed by disparity efficiency growth between sub sectors which exactly experience of negative growth at perception period. The fact sign that policy strategy industrialize during the time not improve yet high level productivity, but on the other hand policy strategy industrialize during the time have enough succeeded to develop equity level between sub sector in manufacture industry.
\end{abstract}

Key words: data envelopment analysis, disparity of technical efficiency, manufacture industry.

Sektor industri manufaktur merupakan salah satu sektor yang mengalami perkembangan yang sangat pesat di Indonesia. Perkembangan industri manufaktur di Indonesia mulai dilakukan secara intensif sejak pemerintahan rejim Orde Baru. Melalui UU No.1 Tahun 1967 tentang Penanaman Modal Asing (PMA), pemerintah melakukan liberalisasi untuk menarik modal asing dengan tujuan menggairahkan perekonomian yang lesu. Proses industrialisasi di Indonesia sebenarnya sudah dimulai sejak kurun waktu 1950-1965, namun adanya kendala politik menyebabkan proses tersebut tidak berjalan lancar. Dampaknya, segala perhatian untuk pembangunan ekonomi menjadi terbengkalai termasuk proses industrialisasi yang sudah direncanakan tidak dapat berjalan sesuai yang diharapkan.

Pembangunan sektor industri manufaktur modern mulai ditata kembali setelah masa pemerintahan Orde Baru. Hal ini terutama karena pemerintah Orde Baru memprioritaskan pada kebijakan pembangunan ekonomi termasuk di dalamnya upaya untuk mempercepat adanya proses industrialisasi. Pada masa Orde Baru, industri manufaktur di Indonesia mulai mengalami pertumbuhan yang cukup signifikan.

Pesatnya perkembangan industri manufaktur dalam perekonomian Indonesia tidak terlepas dari peran yang disumbangkan sektor tersebut terhadap pertumbuhan PDB total (lihat Tabel 1). Pada kurun waktu 1971-1980, peran sektor industri manufaktur sebesar 12,9\%, namun berdasarkan estimasi World Bank pada tahun 1994, pada periode 2000-2010 sektor industri manufaktur diharapkan dapat memberikan kontribusi pada pembentukan PDB Indonesia sebesar 44,5\%, melebihi sektor jasa yang diperkirakan tumbuh $42,4 \%$. Estimasi ini walaupun masih merupakan prediksi jauh sebelum Indonesia terkena krisis ekonomi diduga akan berdampak terhadap 
pertumbuhan sektor industri manufaktur. Prediksi tersebut menggambarkan semakin besarnya peranan sektor tersebut terhadap pertumbuhan PDB Indonesia.

Tabel 1. Kontribusi Sektor Industri Manufaktur pada Pertumbuhan PDB Total Indonesia (\%)

\begin{tabular}{lccc}
\hline & \multirow{3}{*}{ Sektor } & Riil & Estimasi \\
\cline { 2 - 4 } & $1971-1980$ & $1980-1990$ & $2000-2010$ \\
\hline Migas & 28.5 & 3.6 & 0.2 \\
\hline Non Migas & & & 6.4 \\
\hline Pertanian & 13.0 & 13.8 & 44.5 \\
Manufaktur & 12.9 & 23.3 & 42.4 \\
Jasa & 35.7 & 50.4 & 39.4 \\
Lain-lain & 9.8 & 8.9 & 100.0 \\
\hline Total & 100.0 & 100.0 & \\
\hline
\end{tabular}

Sumber : World Bank (1994)

Dari perkembangan yang telah diperlihatkan oleh sektor industri manufaktur, maka tidaklah berlebihan jika dikatakan bahwa sektor industri manufaktur telah menjadi salah satu sektor andalan yang diharapkan dapat meningkatkan dan mendorong terjadinya pertumbuhan ekonomi nasional lebih cepat. Untuk memenuhi harapan tersebut maka dilakukan pembenahan terutama menyangkut kriteria teknis-ekonomis dimana dua faktor penting diantaranya menyangkut tingkat efisiensi dan tingkat produktivitas menjadi sangat penting diperhatikan. Untuk itu perlu dikembangkan penelitian dan rekayasa industri dengan memanfaatkan teknologi untuk menghasilkan produk yang bernilai tinggi.

Hasil studi empiris tentang industri manufaktur di Indonesia dilakukan oleh Sobari pada tahun 2002 menggunakan DEA. Hasil pengukuran tingkat efisiensi rata-rata industri manufaktur pada rentang waktu 1988-1998 sangat berfluktuatif dalam rentang pergerakan hampir tiga sampai empat skala hitung. Perkembangan tingkat efisiensi selama periode pengamatan tidak lebih tinggi dibandingkan periode awal pengamatan.

Beberapa masalah penting yang berkaitan dengan sektor industri manufaktur di Indonesia adalah antara lain masalah kemungkinan terjadinya disparitas tingkat efisiensi dan produktivitas tiaptiap subsektor dari industri manufaktur di Indonesia. Permasalahan tersebut terjadi karena inefisiensi pada tiap-tiap subsektor yang ada dalam sektor industri manufaktur.

Diperlukan penelitian mengenai perubahan tingkat efisiensi dan perubahan yang terjadi dalam pemanfaatan teknologi dalam industri manufaktur di Indonesia. Penelitian ini untuk menjelaskan pentingnya perencanaan terpadu dalam kebijakan pembangunan sektor industri manufaktur. Upaya menerapkan kebijakan tersebut dilandasi oleh pertimbangan bahwa kebijakan pembangunan sektor industri manufaktur harus dalam kerangka kebijakan yang mampu menempatkan prioritas pengembangan industri manufaktur secara terfokus pada jenis-jenis industri manufaktur dengan produktivitas tinggi dan memiliki daya saing. Sehingga tidak terjebak pada kebijakan industri yang berbasis luas (broad base strategy), namun tidak memiliki keunggulan bersaing dengan produk manufaktur lainnya (Sobari, 2002).

Salah satu ukuran representatif dapat digunakan untuk melihat adanya potensi dari setiap subsektor adalah menganalisis ada tidaknya perkembangan tingkat efisiensi dan tingkat kesenjangan antara berbagai subsektor pada sektor industri manufaktur di Indonesia selama rentang periode waktu tertentu. Tulisan ini bertujuan untuk mengukur tingkat efisiensi teknis produksi berbagai 
subsektor atau jenis lapangan usaha sektor industri manufaktur di Indonesia tahun 1990-2002, mengeksplorasi perubahan tingkat disparitas efisiensi produksi antar subsektor dan menganalisis perkembangan tingkat pertumbuhan teknologi menggunakan metode DEA Constant Return to Scale dan DEA Variable Return to Scale

\section{Konsep Efisiensi dalam Perspektif Teori}

Efisiensi teknis produksi menggambarkan pengorbanan atau biaya yang harus ditanggung untuk menghasilkan output tertentu. Hal ini tercermin dalam pemakaian input, di mana jumlah pemakaian input menentukan suatu tingkat produksi tertentu yang telah mencapai kondisi efisien atau sebaliknya. Kenaikan dalam efisiensi teknis menunjukkan bahwa dengan pemakaian input lebih kecil dapat digunakan untuk menghasikan output yang sama. Efisiensi teknis juga dapat diartikan dengan pemakaian input yang sama tetapi dapat menghasilkan output jauh lebih besar. Kemungkinan ini dapat terjadi karena teknik produksi yang lebih baik.

Skala operasi atau skala hasil menunjukkan perubahan output sebagai hasil dari perubahan proportional input. Increasing return to scale apabila penambahan output lebih besar dari penambahan proporsi input. Decreasing return to scale apabila penambahan output lebih kecil dari penambahan proporsi input. Sedangkan constant return to scale apabila penambahan output sebanding dengan penambahan proporsi input.

Pengertian efisiensi dapat dilihat dari berbagai sudut pandang yang berbeda. Efisiensi dapat didefinisikan sebagai rasio antara output dengan input (Kost \& Rosenwig, 1979). Ada tiga faktor yang menyebabkan efisiensi, yaitu apabila dengan input yang sama menghasilkan output yang lebih besar, input lebih kecil menghasilkan output yang sama, dan input besar menghasilkan output yang lebih besar.

Ditinjau dari teori ekonomi, ada dua pengertian efisiensi, yaitu efisiensi ekonomi dan efisiensi teknis. Efisiensi ekonomis mempunyai sudut pandang makro yang mempunyai jangkauan lebih luas dibandingkan dengan efisiensi teknis yang bersudut pandang mikro. Pengukuran efisiensi teknis cenderung terbatas pada hubungan teknis dan operasional dalam proses konversi input menjadi output. Akibatnya, usaha untuk meningkatkan efisiensi teknis hanya memerlukan kebijakan mikro yang bersifat internal, yaitu dengan pengendalian dan alokasi sumber daya yang optimal. Dalam efisiensi ekonomis, harga tidak dapat dianggap given, karena harga dapat dipengaruhi oleh kebijakan makro (Walter, 1995).

Giuffrida \& Gravelle (2001), berpendapat bahwa ada tiga sumber inefisiensi biaya yaitu inefisiensi teknis, inefisiensi alokasi, dan skala inefisiensi. Inefisiensi teknis (technical inefficiency) terjadi jika hanya sedikit output dihasilkan dari sejumlah input tertentu. Tingkat output unit kegiatan ekonomi (UKE) berada jauh di atas garis isokuan. Inefisiensi alokasi (allocative inefficiency) terjadi ketika input digunakan dalam proporsi yang salah, sehingga harga dan produktivitas berada pada satu garis batas. UKE tetap berada pada garis isokuan, tetapi pada titik yang salah. Terakhir, skala inefisiensi (scale inefficiency) terjadi ketika biaya total dapat dikurangi dengan merubah jumlah UKE, dan unit kegiatan ekonomi berada pada garis isokuan yang salah. Penggabungan antara efisiensi teknis dengan efisiensi alokasi akan menghasilkan pengukuran efisiensi ekonomi secara total (total economic efficiency) efisiensi harga (price efficiency) biasa dikenal sebagai pengganti efisiensi alokasi (allocative efficiency), sementara istilah efisiensi secara keseluruhan (overall efficiency) sering digunakan sebagai pengganti istilah efisiensi ekonomi (economic efficiency).

Pengukuran efisiensi yang dikemukakan Farrell (1957) berkaitan dengan ruang input-output (input-output space) sehingga fokus pembahasannya adalah pada upaya pengurangan input (an 
input reducing focus). Metode ini sering disebut pengukuran berorientasi input (input oriented measures).

\section{Intensitas Faktor Produksi}

Intensitas faktor produksi menunjukkan perbandingan relatif antara faktor produksi atau input yang digunakan dalam proses produksi. Salah satu indikator ditunjukkan dengan rasio $\mathrm{K}$ dan $\mathrm{L}$. Proses produksi dikatakan padat modal apabila kapital yang digunakan dalam proses produksi relatif lebih banyak dibandingkan pemakaian input tenaga kerja dan sebaliknya.

Indikator yang digunakan untuk mengukur intensitas faktor produksi adalah dengan melihat perubahan harga relatif dari faktor produksi atau rasio produk marginal atau MRTS dari kedua faktor produksi.

$$
\left(\gamma_{K L}\right)=\frac{(\Delta Q / \Delta L)}{(\Delta Q / \Delta K)}
$$

Sebagai contoh fungsi produksi Cobb Douglas

$$
Q=A K^{\alpha} L^{\beta}
$$

dimana $\mathrm{Q}$ adalah output, $\mathrm{A}$ adalah efisiensi teknis, $\mathrm{K}$ dan $\mathrm{L}$ adalah input kapital dan tenaga kerja, dan $\alpha$ dan $\beta$ adalah elastisitas produksi untuk masing-masing input $\mathrm{K}$ dan $\mathrm{L}$. Tingkat substitusi marginal untuk tenaga kerja atau MRTS $\mathrm{KL}_{\mathrm{L}}$ dapat dinyatakan sebagai:

$$
\left(\gamma_{K L}\right)=\frac{\beta K}{\alpha L}
$$

Dengan asumsi harga input konstan maka semakin besar rasio K/L, teknologi yang digunakan dalam proses produksi bersifat capital intensif dan sebaliknya. Oleh karena itu koefisien dan elastisitas kapital harus lebih besar dibandingkan koefisien atau elastisitas tenaga kerja sehingga kita dapat melihat adanya hubungan yang terbalik antara $\mathrm{K} / \mathrm{L}$ dengan $\beta / \alpha$. Makin rendah rasio $\beta / \alpha$ makin tinggi rasio $\mathrm{K} / \mathrm{L}$ dan teknologi dalam proses produksi makin bersifat capital intensif atau semakin rendah MRTS antara kapital dengan tenaga kerja teknologi produksi makin bersifat capital intensif.

\section{Data Envelopment Analysis}

DEA (Charnes, et.al, (1978), adalah sebuah metode optimasi program matematika yang mengukur efisiensi teknik suatu unit kegiatan ekonomi (UKE) dan membandingkan secara relatif terhadap UKE yang lain. DEA mula-mula dikembangkan oleh Farrel (1957) yang mengukur efisiensi teknik satu input dan satu output, menjadi multi input dan multi output, menggunakan kerangka nilai efisiensi relatif sebagai rasio input (single virtual input) dengan output (single virtual output) (Giuffrida \& Gravelle, 2001; Post \& Spronk, 1999). Awalnya, DEA dipopulerkan oleh Charnes,et al (1978) dengan metode constant return to scale (CRS) dan dikembangkan oleh Banker, et al (1994) untuk variable return to scale (VRS), yang akhirnya terkenal dengan model CCR dan BCC.

DEA merupakan alat analisis yang digunakan untuk mengukur efisiensi, antara lain untuk penelitian kesehatan (healt care), pendidikan (education), transportasi, pabrik (manufacturing), maupun perbankan. Ada tiga manfaat yang diperoleh dari pengukuran efisiensi dengan DEA (Insukindro dkk, 2000), pertama, sebagai tolok ukur untuk memperoleh efisiensi relatif yang berguna untuk mempermudah perbandingan antar unit ekonomi yang sama. Kedua, mengukur berbagai 
variasi efisiensi antar unit ekonomi untuk mengidentifikasi faktor-faktor penyebab, dan ketiga, menentukan implikasi kebijakan sehingga dapat meningkatkan tingkat efisiensi.

Awalnya, DEA digunakan untuk mengatasi kekurangan analisis rasio dan regresi berganda. Analisis rasio hanya mampu memberikan informasi bahwa UKE tertentu yang memiliki kemampuan khusus mengkonversi satu jenis input ke satu jenis output tertentu, sedangkan analisis regresi berganda menggabungkan banyak output menjadi satu. DEA dirancang untuk mengukur efisiensi relatif suatu unit kegiatan ekonomi (UKE) yang menggunakan input dan output yang lebih dari satu, di mana penggabungan tersebut tidak mungkin dilakukan. Efisiensi relatif suatu UKE adalah efisiensi suatu UKE dibanding dengan UKE lain dalam sampel yang menggunakan jenis input dan output yang sama. DEA memformulasikan UKE sebagai program linier fraksional untuk mencari solusi jika model tersebut ditransformasikan kedalam program linier dengan nilai bobot input dan output. UKE dipakai sebagai variabel keputusan (decision variables) menggunakan metode simpleks.

Pada kasus input dan output yang bervariasi, efisiensi suatu UKE dihitung dengan mentransformasikan menjadi input dan output tunggal. Transformasi ini dilakukan dengan menentukan pembobot yang tepat. Penentuan pembobot ini yang selalu menjadi masalah dalam pengukuran efisiensi. DEA digunakan untuk menyelesaikan masalah dengan memberi kebebasan pada setiap UKE untuk menentukan pembobotnya masing-masing.

Konstruksi DEA yang didasarkan frontier data aktual pada sampel akan lebih efisien dibandingkan DEA yang tidak menggunakan frontier. Efisiensi UKE diukur dari rasio bobot output dibagi bobot input (total weighted output/total weighted input). Bobot tersebut memiliki nilai positif dan bersifat universal, artinya setiap UKE dalam sampel harus dapat menggunakan seperangkat bobot yang sama untuk mengevaluasi rasionya (total weighted/total weighted input $\leq 1$ ). Angka rasio 1 (atau kurang dari satu) berarti UKE tersebut efisien (tidak efisien) dalam menghasilkan tingkat output maksimum dari tiap input. DEA berasumsi bahwa setiap UKE menggunakan kombinasi input yang berbeda untuk menghasilkan kombinasi output yang berbeda pula. Sehingga setiap UKE akan memilih seperangkat bobot yang mencerminkan keragaman tersebut. Secara umum UKE akan menetapkan bobot yang tinggi untuk input yang penggunaannya sedikit untuk memaksimalkan output, dan sebaliknya.

\section{Validasi Model}

Validasi model merupakan satu tahapan yang sangat penting dalam proses pembentukan model di mana proses tersebut memberikan kontribusi yang sangat penting untuk memahami fenomena-fenomena ekonomi yang sedang dipelajari. Proses validasi model ini dimaksudkan untuk menyajikan bukti-bukti umum mengenai kegunaan teori dan teknik pembentukan model (Muchdie, 1998)

Untuk mengestimasi efisiensi produksi sektor industri dari tiap-tiap jenis lapangan usaha maka digunakan model dengan $n$ unit pengambilan keputusan atau bisa disebut dengan unit kegiatan ekonomi (UKE) atau decision making unit (DMU).

Asumsi yang dipakai adalah $n$ UKE telah memproduksi s output dari $m$ input yang dipakai. UKE j atau $x^{i j} \geq 0$ menggambarkan input ke-i yang tidak boleh negatip dan $y^{r j} \geq 0$ bermakna bahwa unit output ke-r juga tidak boleh negatip. Simbol lainnya yang digunakan berupa $X_{j}$ yang merupakan vektor input dan yj yang merupakan vektor output. Data input dan output yang telah diobservasi ini nantinya akan digunakan untuk mengkonstruksi sebuah model teknologi acuan 
(reference technology) atau $\mathrm{Tr}$. Model ini akan mengadopsi konsep yang dikembangkan oleh Farrel (1957) yang mengukur efisiensi $X$ berupa rasio input terhadap output.

Tabel 2. Vektor dari set data

\begin{tabular}{|c|c|c|}
\hline UKE & $\begin{array}{l}\text { Output (Y) } \\
1,2, \ldots \ldots \ldots . . . \ldots \ldots \ldots . . .5\end{array}$ & 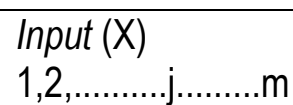 \\
\hline $\begin{array}{l}1 \\
2\end{array}$ & & \\
\hline j & $\ldots \ldots \ldots \cdots \cdots \cdots \cdots \cdots \cdots \cdots$ & $\cdots \cdots \cdots \cdots \cdots \cdots \cdots \cdots \cdots \cdots \cdots \cdots \cdots$ \\
\hline $\mathrm{n}$ & & \\
\hline
\end{tabular}

Dimana $y^{r j} \geq 0$ dan $x^{i j} \geq 0$

\section{Model DEA Constant Return to Scale (CRS)}

Bagian pembahasan ini dapat dimulai dengan mendefinisikan beberapa notasi. Dengan asumsi $\mathrm{K}$ adalah input dan $\mathrm{M}$ adalah output maka untuk setiap perusahaan disebut dengan UKE. Untuk UKE ke-i diwakili secara berturut-turut oleh vektor $\mathrm{x}_{i}$ dan $\mathrm{y}_{\mathrm{i}}$. Dalam hal $\mathrm{X}$ adalah matriks input $\mathrm{K}$ $\mathrm{x} \mathrm{N}$ dan $\mathrm{Y}$ adalah matriks output $\mathrm{M} \mathrm{X} \mathrm{N}$, maka representasi tersebut merupakan cara merumuskan data dalam bentuk matriks dari semua N UKE. Tujuan dari DEA adalah untuk membentuk sebuah frontier non parametric envelopment terhadap sebuah data dari titik pengamatan yang berada di bawah frontier. Salah satu kasus sederhana yang bisa dibuat contoh disini adalah kasus sebuah industri yang memproduksi satu output dengan menggunakan dua buah input, dimana hal tersebut dapat digambarkan dalam sebuah grafik sebagai jumlah pertemuan garis atau bidang yang menyelubungi sebaran titik-titik yang berjarak rapat (scatter) dalam ruang tiga dimensi.

Cara terbaik untuk memperkenalkan DEA adalah melalui bentuk rasio. Untuk setiap UKE kita mendapatkan ukuran rasio dari semua output terhadap semua inputnya seperti U'yj/V'ki, dimana u merupakan vektor $\mathrm{M} \times 1$ dari output tertimbang (weight output) dan $\mathrm{v}$ adalah vektor $\mathrm{k} \times 1$ dari input tertimbang. Untuk memilih penimbang yang optimal kita harus menspesifikasikan problem programasi matematika (the mathematical programming problem) sebagai berikut :

$$
\begin{aligned}
& \operatorname{Max}_{\mathrm{u}, \mathrm{v}}\left(\frac{\mathrm{u}^{\prime} \mathrm{y}_{\mathrm{i}}}{\mathrm{v}^{\prime} \mathrm{x}_{\mathrm{j}} .}\right. \\
& \text { s.t. } \frac{u^{\prime} y_{i}}{v^{\prime} x_{j}} \leq 1, \quad \mathrm{j}=1,2, \ldots, N \\
& u, v \geq 0
\end{aligned}
$$

Dalam hal ini termasuk juga menemukan nilai untuk u dan v sebagai sebuah pengukuran efisiensi dari UKE ke-i yang maksimal dengan tujuan untuk kendala bahwa semua ukuran efisiensi haruslah kurang dari atau sama dengan satu. Salah satu masalah dengan formulasi atau rumusan rasio ini adalah bahwa ia memiliki sejumlah solusi yang tidak terbatas (infinite), artinya jika $\left(u^{*}, v^{*}\right)$ 
adalah solusi maka $\left(\alpha u^{*}, \alpha v^{*}\right)$ juga solusi yang lain. Untuk menghindari hal ini maka kita dapat menentukan kendala $u^{\prime} x_{i}=1$ yang menetapkan bahwa :

$$
\begin{aligned}
& \operatorname{Max} \mu, v\left(\mu^{\prime}, y_{j}\right) \\
& \text { s.t. } v^{*} x_{i}=1 \\
& \mu^{\prime}, y-v_{j} \leq 0, j=1,2, \ldots, n \\
& \mu, v \geq 0
\end{aligned}
$$

dimana notasi tersebut berubah dari $u$ dan v menjadi $\mu$ dan $v$ yang menunjukkan terjadinya transformasi. Bentuk ini dikenal sebagai bentuk pengganda (multiplier form) dari problem programasi linier (linier programming problem).

Dengan menggunakan model dualitas (duality) dalam programasi linier maka dapat diturunkan bentuk kurva amplop (envelopment) yang ekuivalen atau sama dengan problem diatas yaitu :

$$
\begin{gathered}
\text { Min } \theta, \lambda \theta, \\
\text { s.t. }-y_{i}+y \lambda \geq 0, \\
\theta x_{i}-x \lambda \geq 0 \\
\lambda \geq 0
\end{gathered}
$$

dimana $\theta$ merupakan skalar dan $\lambda$ adalah konstanta dari vektor $\mathrm{N} \times 1$. Bentuk envelopment ini melibatkan lebih sedikit kendala (constraint) daripada bentuk multiplier $(\mathrm{K}+\mathrm{M}<\mathrm{N}+1)$ dan telah dijadikan acuan umum untuk memecahkan permasalahan yang dihadapi. Nilai dari $\theta$ yang diperoleh merupakan angka efisiensi untuk UKE ke-i. Hal itu memenuhi nilai $\theta \leq 1$ dimana nilai 1 menunjukkan sebuah titik yang ada di garis batas kemungkinan produksi (frontier) karena itu disebut UKE yang efisiensi secara teknis mengacu pada definisi yang telah ditentukan oleh Farrel (1957). Dengan memperhatikan bahwa problem programasi linier haruslah dipecahkan sebanyak $\mathrm{N}$ kali untuk setiap UKE dalam sampel maka nilai $\theta$ kemudian dapat diperoleh untuk setiap UKE.

\section{Model DEA Variable Return to Scale (VRS)}

Model CRS hanya cocok jika semua UKE yang beroperasi pada skala yang optimal (dalam hal ini sebuah UKE menghadapi porsi yang sama (flat portion) untuk kurva LRAC). Persaingan tidak sempurna, kendala keuangan dan sebagainya mungkin menyebabkan sebuah UKE tidak beroperasi pada skala yang optimal. Banker, et al (1984) menganjurkan sebuah perluasan dari model CRS DEA dengan menerapkan VRS. Penggunaan dari spesifikasi CRS ketika tidak semua UKE beroperasi pada skala yang optimal akan menghasilkan pengukuran technical efficiency (TE) yang berbaur atau dikacaukan (confounded) dengan hasil pengukuran efisiensi skala (scale efficiency/SE). Kegunaan dari spesifikasi VRS ini akan memungkinkan perhitungan TE yang dapat menghilangkan sama sekali efek dari SE ini.

Problem programasi linier untuk kasus CRS dapat dengan mudah dimodifikasi untuk menjelaskan pendekatan VRS dengan cara menambahkan kendala konveksitas (convexity constraint) : $N_{1}^{\prime} \lambda=1$ kedalam persamaan (6) sehingga rumusnya menjadi: 


$$
\begin{gathered}
\operatorname{Min} \theta, \lambda, \theta \\
\text { s.t. }-y_{i}+y \lambda \geq 0 \\
\theta x_{i}-y \lambda \geq 0 \\
N_{i} \lambda=1 \\
\lambda \geq 0
\end{gathered}
$$

dimana $\mathrm{N}_{1}$ merupakan vektor $\mathrm{N} \times 1$. Pendekatan VRS ini membentuk sebuah garis persinggungan yang cembung yang menyelimuti atau menyampuli data secara lebih ketat dibanding dengan pendekatan CRS yang berbentuk lambung kapal (conical hull) dan nilai efisiensi teknis yang didapatkan dari pendekatan ini lebih besar atau sama dengan yang dihasilkan jika menggunakan pendekatan CRS. Spesifikasi VRS ini telah digunakan secara umum sejak tahun 1990-an.

Pada teknologi variable return to scale, maka efisiensi berada pada garis ABDV. Dengan asumsi ini maka titik $A, B, D$, dan $V$ dikatakan efisien.

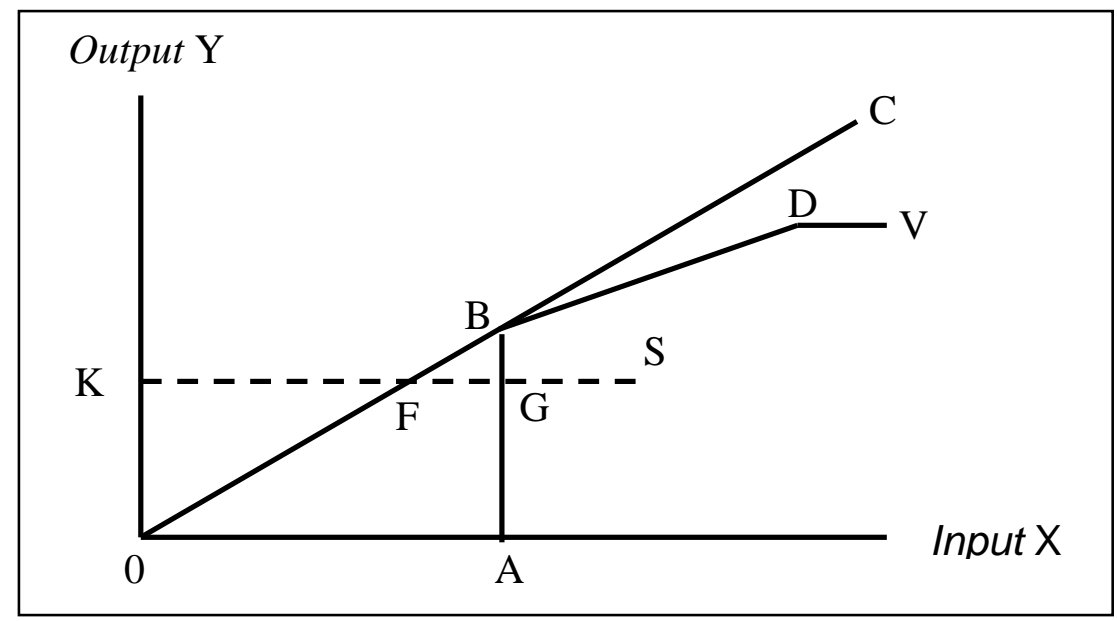

Gambar 1. Pendekatan satu input dan satu output

Programasi linier yang menunjukkan asumsi VRS adalah :

$$
\begin{gathered}
\text { Maksimisasi } h_{s}=\sum_{i=1}^{m} u_{i} y_{i s}+U_{o} \\
\text { Kendala } \sum_{i=1}^{m} u_{i} y_{i r}-\sum_{j=1}^{n} v_{j} x_{j r} \leq 0, r=1, \ldots . . N ; \\
\sum_{j=1}^{n} v_{j} x_{j s}=1, u_{i} \text { dan } v_{j} \geq 0
\end{gathered}
$$

dimana $U_{o}$ merupakan penggal yang dapat bernilai positif atau negatif. Transformasi juga dapat dilakukan secara dual dengan minimisasi input sebagai berikut:

Minimisasi $\beta_{s}$ 


$$
\text { Kendala } \begin{aligned}
& \sum_{r=1}^{n} \theta_{r} y_{i r} \geq y_{i s}, i=1, \ldots, m \\
& \beta_{s} x_{j s}-\sum_{r=1}^{N} \theta_{r} x_{i r} \geq 0, j=1, \ldots, n ; \theta_{r} \geq 0 ; \text { dan } \beta_{s} \text { bebas }
\end{aligned}
$$

Variabel $\beta_{\mathrm{s}}$ merupakan efisiensi teknis dan bernilai antara 0 dan 1. Programasi linier pada persamaan (9) diasumsikan constant return to scale (CRS). Efisiensi teknis $\left(\beta_{\mathrm{s}}\right)$ diukur sebagai rasio KF/KS dan bernilai kurang dari satu. Sementara $\left(1-\beta_{\mathrm{s}}\right)$ menerangkan jumlah input yang harus dikurangi untuk menghasilkan output yang sama sebagai bentuk efisiensi bank seperti yang ditunjukkan oleh titik $F$. Kedua perhitungan, minimisasi input atau maksimisasi output, primal atau dual akan memberikan hasil yang relatif sama, sehingga dalam tuisan ini akan menghitung efisiensi dari satu sisi yaitu maksimisasi output. Perhitungan teknis model ini akan dilakukan menggunakan software Warwick DEA.

\section{Pengukuran Tingkat Disparitas Efisiensi}

Pengukuran tingkat disparitas efisiensi antara subsektor (jenis lapangan usaha/ISIC 3 digit) dalam sektor industri manufaktur di Indonesia dilakukan dengan menggunakan indikator berupa nilai koefisen variasi (coefficient of variation/CV) (Jefferson \& Wu, 1994). Secara matematis, koefisien ini dirumuskan sebagai berikut :

$$
C V_{i}=\frac{S D\left(M E_{i j}\right)}{M E_{i j}}
$$

dimana CV = coefficient of variation, $\mathrm{SD}=$ standar deviasi dari efisensi rata-rata keseluruhan UKE $\mathrm{i}$ pada periode j, sedangkan ME adalah tingkat efisiensi rata-rata keseluruhan UKE i pada periode j tertentu dan nilai koefisien tersebut terletak antara 0 sampai dengan 1. Interpretasi koefisen tersebut dapat dijelaskan sebagai berikut: semakin mendekati angka nol maka akan semakin rendah tingkat disparitas antar subsektor dalam sektor industri manufaktur pada periode j. Demikian sebaliknya semakin mendekati nilai satu maka semakin besar tingkat disparitas antar subsektor dalam industri manufaktur pada periode $\mathrm{j}$.

\section{Variabel Penelitian}

Klasifikasi industri yang digunakan dalam penelitian ini adalah 30 subsektor berdasarkan klasifikasi ISIC 3 (versi BPS) selama 12 tahun mulai tahun 1990 sampai tahun 2002. Data yang dianalisis mencakup :

1. Nilai output (barang yang dihasilkan) dari berbagai subsektor (jenis lapangan usaha) ISIC 3 sektor industri manufaktur berskala menengah dan besar $\left(\mathrm{y}_{\mathrm{j}}\right)$

2. Jumlah pekerja pada sektor industri ditiap-tiap subsektor $\left(X_{1}\right)$

3. Nilai selisih antara biaya pembelian baru atau bekas dan perbaikan dari barang-barang kapital tetap dengan pendapatan yang diperoleh dari hasil penjualan barang-barang kapital tetap/fixed capital $\left(\mathrm{X}_{2}\right)$

4. Biaya sewa, gedung, mesin dan alat-alat sektor industri ditiap-tiap subsektor (jenis lapangan usaha) $\left(X_{3}\right)$

5. Biaya konsumsi bahan bakar/tenaga listrik dan gas sektor industri di tiap-tiap subsektor (jenis lapangan usaha) $\left(\mathrm{X}_{4}\right)$ 


\section{HASIL DAN PEMBAHASAN}

Hasil perhitungan menggunakan program DEA Warwick menunjukkan perkembangan tingkat efisiensi dan perkembangan tingkat disparitas pada rentang pengamatan 1990 sampai 2002. Hasil selengkapnya dapat dilihat pada Tabel 3. Tabel ini memuat hasil perhitungan yang dilakukan dengan asumsi constant return to scale (CRS) dan variable return to scale (VRS).

Hasil perhitungan menggambarkan estimasi selama sepuluh tahun perkembangan kinerja sektor industri manufaktur Indonesia yang relatif meningkat. Hasil ini didukung oleh laporan BPS bahwa nilai efisiensi yang dihitung berdasarkan rasio keseluruhan nilai input bahan mentah dan bahan penolong terhadap nilai keseluruhan output yang dihasilkan untuk perusahaan-perusahaan yang berskala besar relatif meningkat dari tahun 1995 sampai tahun 1997 yaitu sebesar $62 \%$ dan pada tahun 1998 sebesar 65\%. Pada periode yang sama efisiensi perusahaan menengah juga relatif meningkat dari $62 \%$ menjadi $63 \%$ (BPS, 2001). Temuan ini juga didukung oleh hasil kajian oleh Sobari (2002) yang menemukan nilai efisiensi berkisar antara 73\% sampai 88\%.

Dengan metode CRS, pada tahun 1990 nilai rata-rata hasil efisiensi mengalami peningkatan dari $51,73 \%$ dan pada tahun 2002 menjadi $62,27 \%$. Sementara perhitungan menggunakan metode VRS diperoleh hasil efisiensi tahun 1990 sebesar 63,6\% dan cenderung meningkat pada tahun 2002 menjadi $66,8 \%$.

Sebaliknya, kondisi ini berbeda dengan perkembangan disparitas efisiensi antar subsektor yang justru mengalami perkembangan negatif pada periode pengamatan. Kondisi ini ditandai oleh menurunnya nilai koefisien variasi baik dengan asumsi CRS maupun dengan asumsi VRS pada awal pengamatan dibandingkan dengan akhir pengamatan. Perhitungan menggunakan metode CRS diperoleh nilai koefisien variasi pada tahun 1990 sebesar 0,5250301 (52,5\%) dan relatif menurun menjadi 0,478256) $(47,8 \%)$ pada tahun 2002. Perhitungan menggunakan metode VRS hasilnya juga relatif sama. Pada tahun 1990, nilai koefisien variasinya adalah 0,466053 $(46,6 \%)$ dan perhitungan pada tahun 2002 mendapatkan angka 0,458707 (45,87\%).

Dari hasil pengamatan terdapat dua subsektor yang sudah mencapai tingkat efisiensi penuh menurut metode CRS maupun VRS pada tahun 1990 dan 2002 yaitu subsektor industri pengolahan tembakau dan bumbu rokok (ISIC 314) dan industri pemurnian dan pengilangan minyak bumi serta gas bumi (ISIC 353). Perhitungan dengan asumsi CRS menyatakan bahwa terjadi penurunan efisiensi untuk sembilan subsektor industri seperti yang diperlihatkan pada Tabel 4.

Penurunan terbesar dialami oleh subsektor industri kimia (ISIC 352) yaitu hampir 60\% diikuti oleh subsektor industri semen, kapur dan barang dari semen dan kapur yaitu sebesar $58,35 \%$.

Penurunan efisiensi yang paling kecil dicapai oleh subsektor industri logam dasar besi dan baja (ISIC 371) yaitu sebesar $3,05 \%$. Penurunan ini disebabkan belum maksimalnya alokasi penggunaan input untuk memaksimalkan output. Selain sembilan subsektor tersebut, subsektor industri lainnya mengalami peningkatan.

Dari hasil perhitungan dengan metode VRS diperoleh hasil bahwa terjadi penurunan efiensi untuk 10 subsektor industri. Penurunan terbesar terjadi pada subsektor industri karet dan barang dari karet (ISIC 363) dengan nilai efisiensi mencapai 58,14\% disusul oleh industri barang dari logam (ISIC 382 ) sebesar $54,75 \%$. Penurunan efisiensi yang paling kecil dicapai oleh subsektor industri semen, kapur dan barang dari semen dan kapur (ISIC 369) yaitu sebesar 2,2\%. 
Tabel 3. Perkembangan Tingkat Efisiensi dan Tingkat Disparitas antar Sub-Sektor dalam Industri Manufaktur Indonesia Tahun 1990 dan Tahun 2002.

\begin{tabular}{|c|c|c|c|c|c|}
\hline \multirow{2}{*}{ ISIC } & \multirow{2}{*}{ JENIS LAPANGAN USAHA } & \multicolumn{2}{|c|}{1990} & \multicolumn{2}{|c|}{2002} \\
\hline & & CRS & VRS & CRS & VRS \\
\hline 311 & Industri makanan & 45.13 & 100.00 & 51.03 & 51.05 \\
\hline 313 & industri minuman & 65.33 & 65.33 & 68.42 & 69.43 \\
\hline 314 & industri pengolahan tembakau dan bumbu rokok & 100.00 & 100.00 & 100.00 & 100.00 \\
\hline 321 & industri tekstil & 25.54 & 65.64 & 60.33 & 100.00 \\
\hline 322 & industri pakaian jadi kecuali alas kaki & 31.99 & 31.99 & 47.42 & 53.60 \\
\hline 323 & industri alas dan barang dari kulit kecuali untuk alas kaki & 45.75 & 45.75 & 55.18 & 55.40 \\
\hline 324 & industri alas kaki & 32.31 & 32.31 & 45.56 & 49.63 \\
\hline 331 & industri kayu, bambu, rumput, rotan dan sejenisnya & 37.60 & 81.09 & 54.75 & 54.78 \\
\hline 332 & $\begin{array}{l}\text { industri perabotan dan kelengkapan rumah tangga serta alat } \\
\text { dapur dari bambu kayu dan rotan }\end{array}$ & 22.28 & 22.28 & 56.51 & 59.98 \\
\hline 341 & industri kertas barang dari kertas dan sejenisnya & 35.57 & 69.95 & 83.12 & 100.00 \\
\hline 342 & industri percetaan dan penerbitan & 43.56 & 43.56 & 73.37 & 74.50 \\
\hline 351 & industri bahan kimia industri & 51.09 & 100.00 & 83.71 & 100.00 \\
\hline 352 & industri kimia lain & 68.63 & 88.22 & 8.72 & 8.82 \\
\hline 353 & $\begin{array}{l}\text { industri pemurnian dan pengilangan minyak bumi serta gas } \\
\text { bumi }\end{array}$ & 100.00 & 100.00 & 100.00 & 100.00 \\
\hline 354 & $\begin{array}{l}\text { industri barang-barang dari hasil kilang minyak bumi dan } \\
\text { batu bara }\end{array}$ & 16.56 & 54.98 & 100.00 & 100.00 \\
\hline 355 & industri karet dan barang dari karet & 100.00 & 100.00 & 58.74 & 64.16 \\
\hline 356 & industri barang dari plastik & 30.73 & 30.73 & 42.44 & 43.20 \\
\hline 361 & industri porselin & 16.56 & 16.56 & 85.42 & 88.06 \\
\hline 362 & industri gelas dan barang dari gelas & 42.58 & 42.58 & 100.00 & 100.00 \\
\hline 363 & industri semen, kapur dan barang dari semen dan kapur & 78.23 & 78.23 & 19.88 & 20.09 \\
\hline 364 & industri pengolahan tanah liat & 32.29 & 32.29 & 61.93 & 78.02 \\
\hline 369 & industi barang galian bukan logam & 17.41 & 17.41 & 7.15 & 15.21 \\
\hline 371 & industri logam dasar besi dan baja & 100.00 & 100.00 & 96.95 & 100.00 \\
\hline 372 & industri logam dasar bukan besi & 100.00 & 100.00 & 70.87 & 70.92 \\
\hline 381 & industri barang dari logam kecuali mesin dan peralatannya & 53.02 & 64.17 & 16.04 & 22.14 \\
\hline 382 & industri mesin dan perlengkapannya kecuali mesin listrik & 62.76 & 62.76 & 7.34 & 8.01 \\
\hline 383 & $\begin{array}{l}\text { industri mesin, peralatan dan perlengkapan listrik serta } \\
\text { bahan keperluan listrik }\end{array}$ & 70.40 & 90.75 & 67.04 & 68.33 \\
\hline 384 & industri alat angkutan & 54.98 & 100.00 & 100.00 & 100.00 \\
\hline 385 & $\begin{array}{l}\text { industri peralatan profesional, ilmu pengetahuan, pengukur } \\
\text { dan pengatur }\end{array}$ & 42.76 & 42.76 & 100.00 & 100.00 \\
\hline 390 & industri pengolahan lainnya & 28.83 & 28.83 & 46.24 & 49.37 \\
\hline & Minimum & 16.56 & 16.56 & 7.15 & 8.01 \\
\hline & Maksimum & 100 & 100.00 & 100.00 & 100.00 \\
\hline & Rata-rata & 51.73 & 63.60 & 62.27 & 66.82 \\
\hline & Standar Deviasi & 27.16 & 29.64 & 29.78 & 30.65 \\
\hline & CV & 0.52 & 0.46 & 0.48 & 0.46 \\
\hline
\end{tabular}

Sumber: Hasil perhitungan DEA 
Tabel 4. Penurunan Tingkat Efisiensi dengan Metode CRS

\begin{tabular}{rlr}
\hline ISIC & \multicolumn{1}{c}{ JENIS LAPANGAN USAHA } & PERSEN \\
\hline 352 & industri kimia lain & 59,91 \\
355 & industri karet dan barang dari karet & 41,26 \\
363 & industri semen, kapur dan barang dari semen dan kapur & 58,35 \\
369 & industi barang galian bukan logam & 10,26 \\
371 & industri logam dasar besi dan baja & 3,05 \\
372 & industri logam dasar bukan besi & 29,13 \\
381 & industri barang dari logam kecuali mesin dan peralatannya & 33,98 \\
382 & industri mesin dan perlengkapannya kecuali mesin listrik & 55,42 \\
383 & industri mesin, peralatan dan perlengkapan listrik serta bahan keperluan listrik & 3,36 \\
\hline
\end{tabular}

Tabel 5. Penurunan Tingkat Efisiensi dengan Metode VRS

\begin{tabular}{clc}
\hline ISIC & \multicolumn{1}{c}{ JENIS LAPANGAN USAHA } & PERSEN \\
\hline 311 & Industri makanan & 48,95 \\
331 & Industri makanan & 26,81 \\
352 & industri kayu, bambu, rumput, rotan dan sejenisnya & 7,94 \\
355 & industri kimia lain & 35,84 \\
363 & industri karet dan barang dari karet & 58,14 \\
369 & industri semen, kapur dan barang dari semen dan kapur & 2,20 \\
372 & industi barang galian bukan logam & 29,08 \\
381 & industri logam dasar bukan besi & 42,03 \\
382 & industri barang dari logam kecuali mesin dan peralatannya & 54,75 \\
383 & industri mesin dan perlengkapannya kecuali mesin listrik & 22.42 \\
\hline
\end{tabular}

Secara keseluruhan nilai koefisien variasi mulai tahun 1990 sampai 2002 dapat dilihat pada Gambar 2. Dari grafik tersebut terlihat bahwa nilai CV yang fluktuatif dari tahun ke tahun. Namun melihat perkembangan secara keseluruhan terjadi penurunan tingkat disparitas efisensi sektor industri manufaktur di Indonesia.

Perbedaan nilai efisiensi rata-rata secara keseluruhan subsektor (lapangan usaha) dalam sektor industri manufaktur berskala besar dan menengah di Indonesia antara tahun 1990 sampai 2002, baik dengan metode CRS maupun VRS berturut-turut adalah sebesar $-10,54 \%$ dan $-3,21 \%$. Angka negatif untuk perbedaan rata-rata dengan pendekatan CRS dan VRS menunjukkan bahwa telah terjadi penurunan nilai efisiensi rata-rata keseluruhan subsektor dalam sektor industri manufaktur Indonesia pada tahun 2002 dibandingkan tahun 1990. Dengan demikian dapat dikatakan bahwa struktur industri manufaktur Indonesia mengalami penurunan efisiensi pada periode pengamatan.

Fakta empiris tersebut mengindikasikan meskipun pemerintah telah menggulirkan sektor riil sejak tahun 1986 namun kenyataan menunjukkan bahwa deregulasi tersebut tidak efektif terhadap upaya peningkatan daya saing sebagaimana yang diharapkan terwujud kebijakan-kebijakan tersebut. Penyebab lainnya adalah imbas krisis moneter sektor industri manufaktur Indonesia pada pertengahan tahun 1997 yang berakibat lumpuhnya sektor riil. 


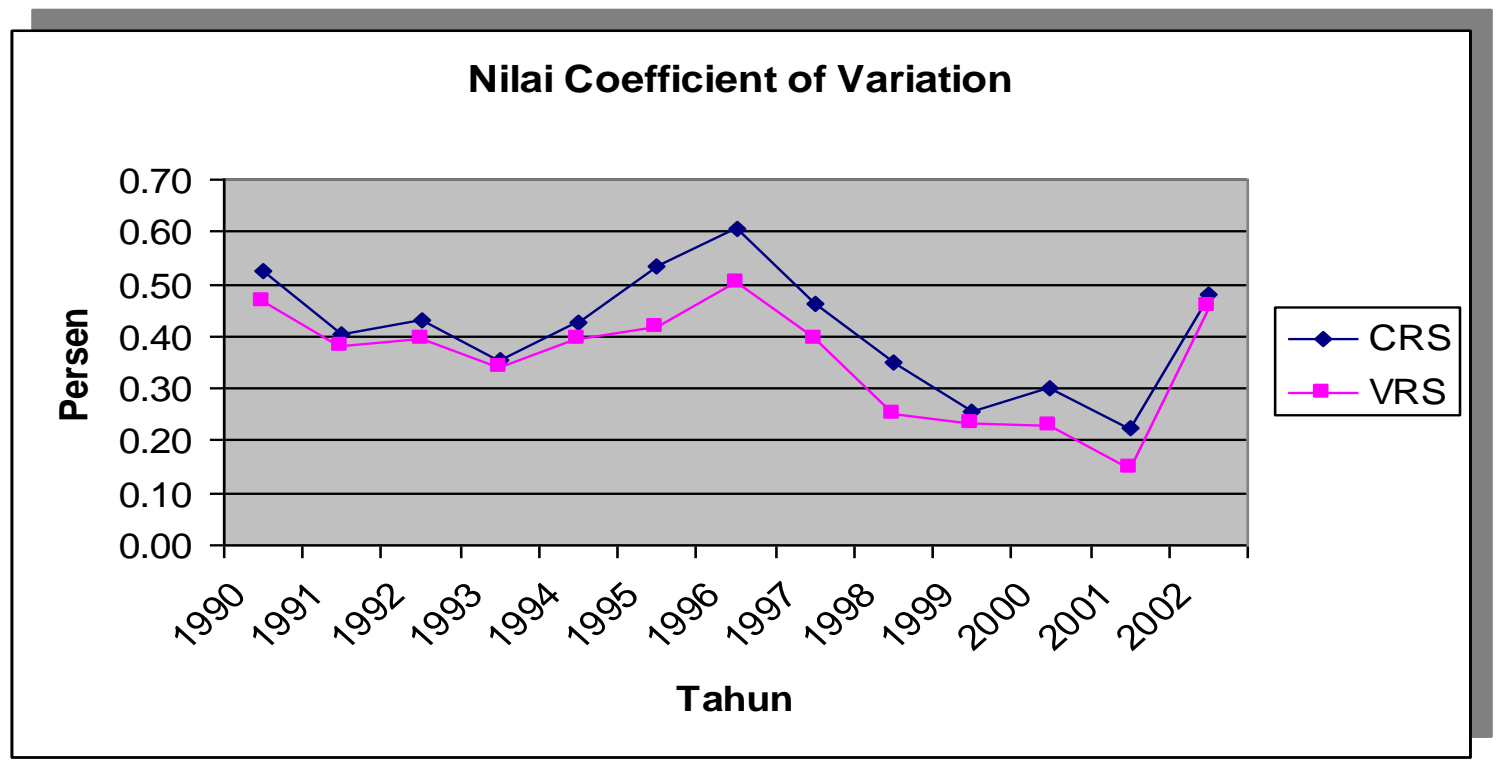

Gambar 2. Nilai Coefficient of Variation

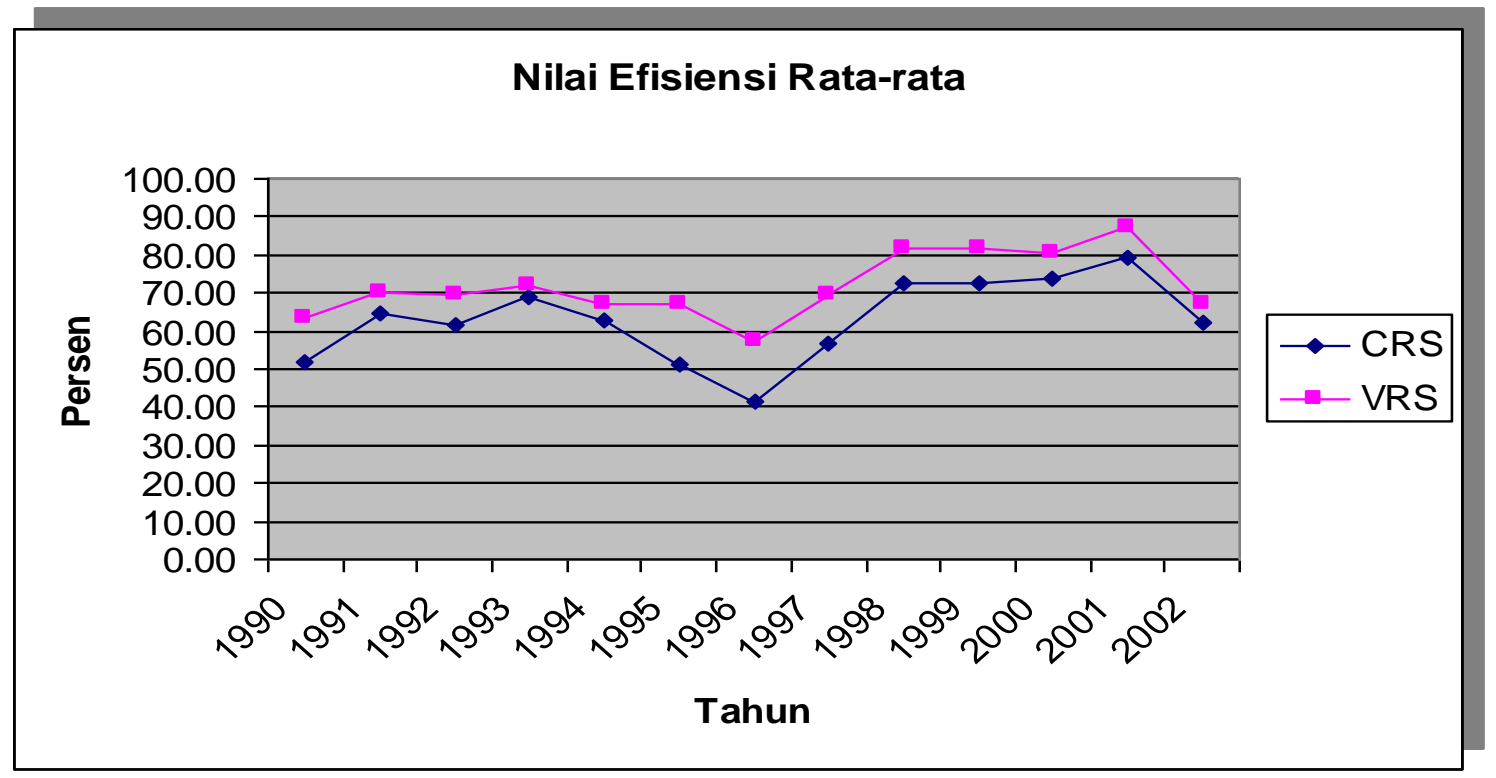

Gambar 3. Nilai Efisiensi Rata-rata

Nilai efisiensi rata-rata terbesar terjadi pada tahun 2000 (dengan asumsi VRS). Peningkatan nilai efisiensi tersebut karena input sudah didayagunakan dengan baik sehingga dapat memaksimalkan output. Temuan ini didukung oleh data yang dikeluarkan oleh Badan Pusat Statistik yang menyatakan bahwa tingkat Pertumbuhan PDB Indonesia pada tahun 2000 naik secara signifikan yaitu dari $0,8 \%$ menjadi $4,9 \%$ dan pertumbuhan sektor industri manufaktur meningkat hampir 90\% dari 3,9\% pada tahun 1999 menjadi 6\% pada tahun 2000 (BPS, 2001).

Hasil efisiensi secara keseluruhan dengan metode CRS menunjukkan bahwa pada nilai efisiensi terkecil terdapat pada tahun 1994 (lihat Gambar 4). Hal ini disebabkan belum dimaksimalkannya penggunaan input untuk produksi. Hasil ini sejalan dengan penelitian yang 
dilakukan oleh UNDP/UNIDO Project yang menyatakan bahwa selama kurun waktu 1994-1997 pertumbuhan sektor industri manufaktur melamban dengan laju rata-rata $12 \%$ setahun, sedangkan pertumbuhan ekspor hasil-hasil industri manufaktur turun sampai rata-rata $8 \%$ setahun. Pertumbuhan yang lebih lamban dalam ekspor hasil-hasil industri terutama disebabkan oleh kemerosotan tajam dalam pertumbuhan ekspor hasil-hasil industri Indonesia seperti yaitu: kayu lapis, tekstil, garmen dan alas kaki, dari 28\% pada 1989 menjadi 2\% rata-rata setahun selama kurun waktu 1994-1997.

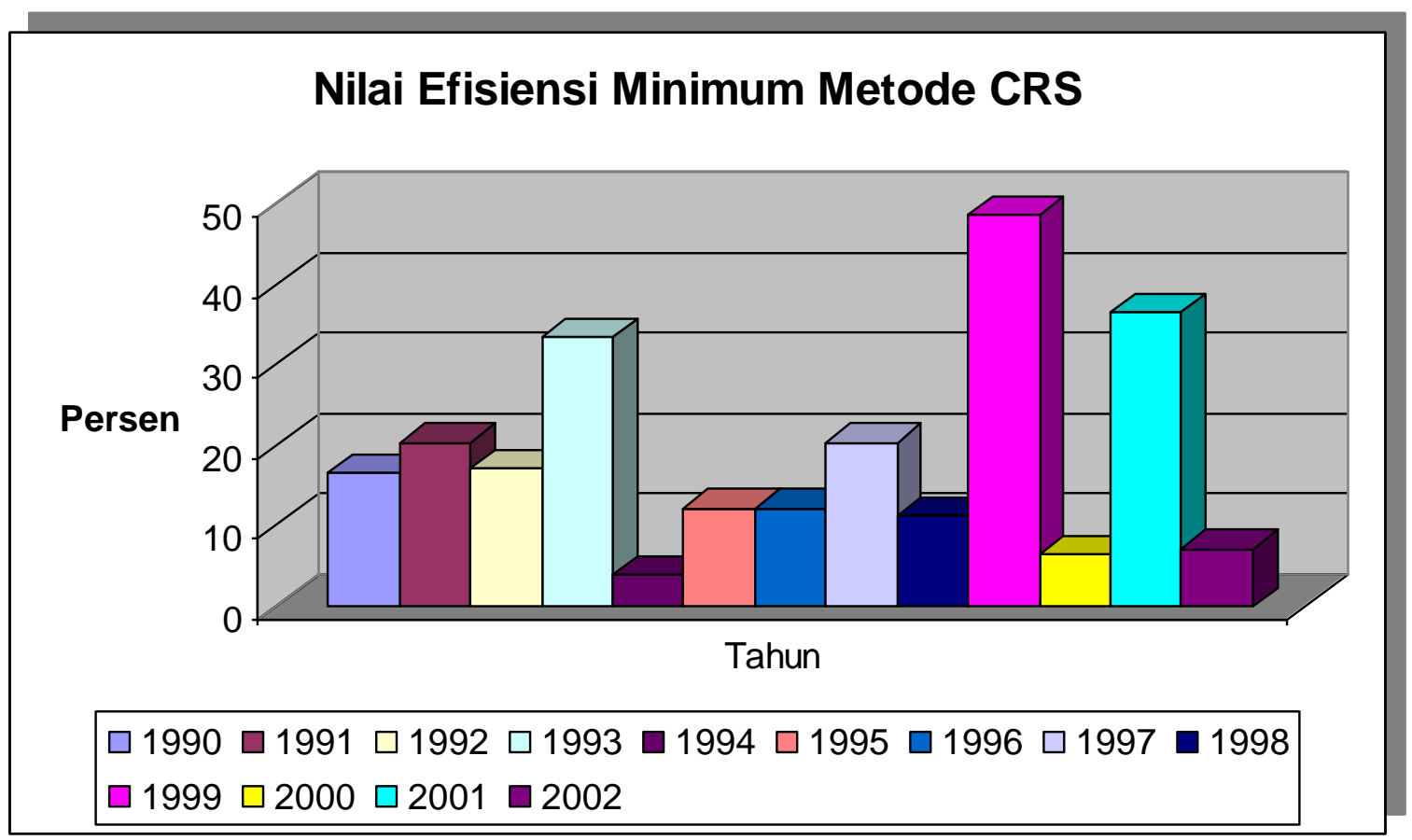

Gambar 4. Nilai Efisiensi Minimum dengan Metode CRS

Sementara itu nilai efisiensi terbesar adalah tahun 1999. Hal ini dimungkinkan karena pasca krisis ekonomi pada tahun 1999, sektor industri sudah melakukan pembenahan yang signifikan sehingga kinerja industri manufaktur di Indonesia terus meningkat.

Dari perhitungan dengan metode VRS didapatkan hasil yang relatif sama dengan metode CRS dimana efisiensi yang paling kecil pada tahun 1994 yaitu sebesar 3,79\% dan nilai efisiensi terbesar dicapai tahun 2001 yaitu sebesar $66.11 \%$ (lihat Gambar 5). Tingginya tingkat efisiensi ini diakibatkan oleh penggunaan input yang optimal untuk menghasilkan output. Sejak tahun 1996 efisiensi industri manufaktur di Indonesia mengalami peningkatan secara terus menerus, namun pada tahun 2002 mengalami penurunan yang sangat berarti. Hasil ini sesuai dengan fakta yang terjadi di Indonesia bahwa selama kurun waktu tersebut, tingkat harga umum (general price level) di Indonesia telah meningkat $24 \%$, yang disebabkan oleh kenaikan tarif listrik (102\%), bahan bakar minyak, BBM (52\%) , minyak diesel (159\%), air (27\%) dan transport (32\%). Kondisi ini sangat memukul kinerja sektor industi manufaktur di Indonesia. 


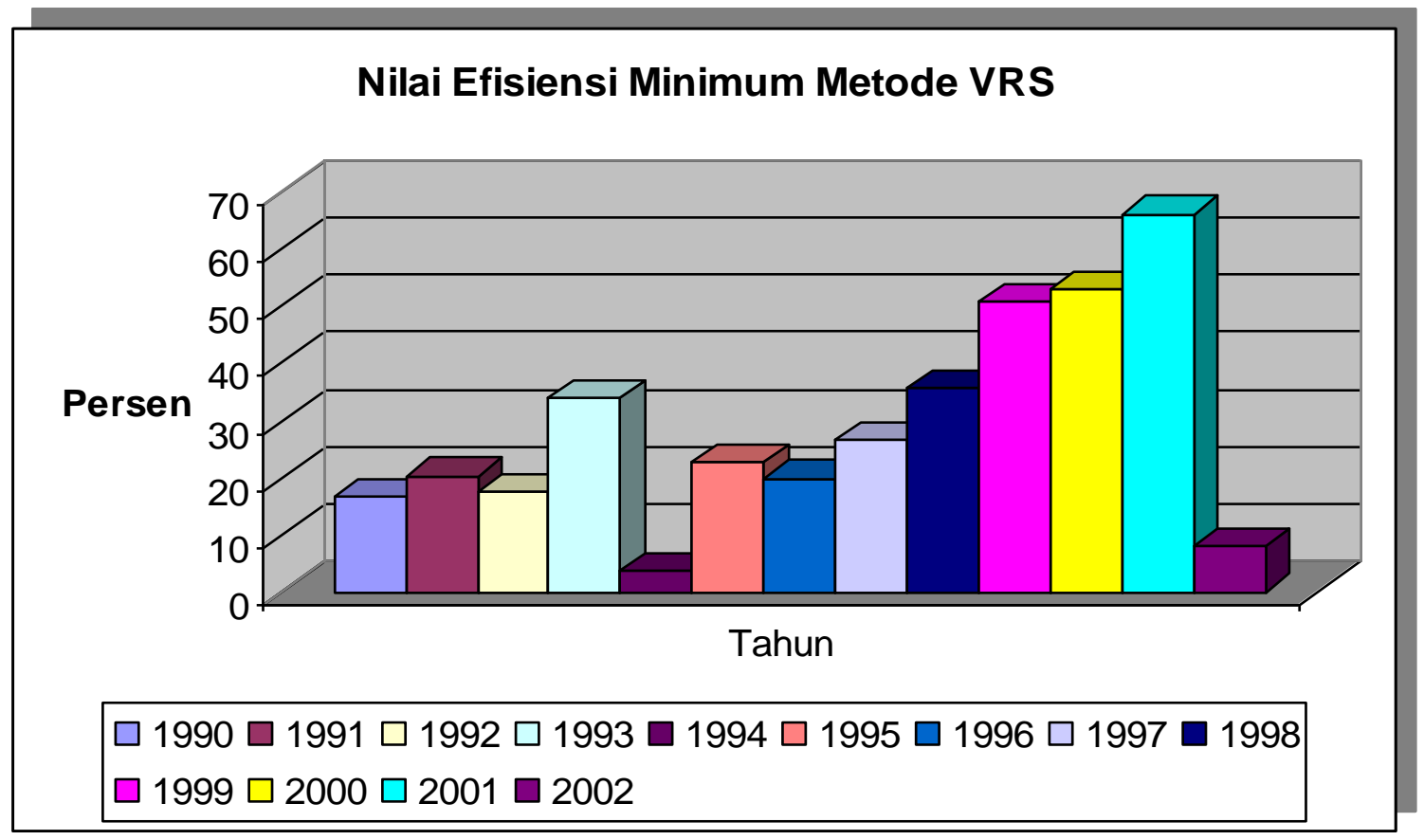

Gambar 5. Nilai Efisiensi Minimum dengan Metode VRS

Dengan hasil empiris tersebut maka dugaan bahwa adanya disparitas dalam endowment factor untuk setiap subsektor dalam industri manufaktur dapat menyebabkan terjadinya disparitas dalam tingkat efisiensi antar subsektor dalam industri manufaktur di Indonesia terbukti. Beberapa subsektor yang bisa dikatakan telah mempunyai keunggulan komparatif karena murahnya tenaga kerja, ketersediaan bahan baku yang cukup melimpah didalam negeri, adanya proteksi penguasaan pasar domestik atau juga ada beberapa subsektor yang berbasis teknologi seperti industri elektronik dan alat listrik.

Studi yang dilakukan oleh World Bank (1997) menunjukkan bahwa tingkat proteksi (nominal dan efektif) sektor industri manufaktur di Indonesia sangat bervariasi menurut subsektor. Salah satu penemuan dari studi ini dapat memperkuat argumen di atas adalah terungkapnya bukti empiris bahwa tingkat proteksi kelompok industri barang dari logam dan bukan logam, serta industri barang modal (engeenering) termasuk dalam kelompok yang tinggi tingkat proteksi efektifnya diantara kelompok-kelompok industri lainya.

\section{PENUTUP}

Secara umum tulisan ini menunjukkan perkembangan kinerja sektor industri manufaktur Indonesia dalam rentang pengamatan 1990 dan 2002 yang relatif stabil, walaupun pada saat krisis moneter 1997 mengalami penurunan namun tidak signifikan. Namun kondisi tersebut tidak diikuti oleh perkembangan disparitas efisiensi antar subsektor yang justru mengalami perkembangan negatif pada periode pengamatan. Kondisi ini ditandai oleh menurunnya nilai koefisien variasi baik dengan asumsi CRS maupun dengan asumsi VRS pada awal pengamatan dibandingkan dengan akhir pengamatan.

Fakta tersebut mengisyaratkan bahwa strategi kebijakan industrialisasi selama ini belum mampu meningkatkan tingkat produktivitas (efisiensi) produksi yang lebih tinggi lagi ditandai dengan 
stabilnya tingkat rata-rata efisiensi secara keseluruhan subsektor dalam industri manufaktur nasional selama dalam rentang pengamatan. Namun pada sisi lain strategi kebijakan industrialisasi selama ini telah cukup berhasil mengembangkan tingkat kemerataan antar subsektor.

Dari temuan tersebut maka rekomendasi kebijakan yang bisa disarankan adalah sebagai berikut. Pertama, perlu diupayakan kembali strategi pengembangan sektor industri manufaktur nasional apakah akan mengambil kebijakan strategi industrialisasi berbasis luas (broad base strategy) atau industrialisasi dengan strategi yang berbasis keunggulan khusus pada subsektor yang efisien. Hal ini perlu dilakukan untuk menjaga kelangsungan proses industrialisasi itu sendiri. Apabila strategi yang diambil adalah strategi industri berbasis luas maka perlu diperhatikan adanya berbagai disparitas dalam perkembangan tingkat efisiensi produksi, baik dilihat antar subsektor pada periode waktu tertentu maupun jika dilihat perkembangannya dari tahun ketahun.

Kedua, adanya disparitas tingkat efisiensi antar subsektor dalam industri manufaktur diduga erat kaitannya dengan adanya indikasi bahwa beberapa subsektor yang selama ini menikmati berbagai kelebihan dalam struktur ongkos, permodalan, teknologi, dan berbagai fasilitas kemudahan lainnya. Dengan demikian agar tingkat disparitas efisiensi antar subsektor menjadi kecil perlu diupayakan proses industrialisasi dengan dukungan kebijakan yang tepat dan terfokus terutama untuk sektor yang selama ini diduga kuat mempunyai daya serap tinggi terhadap input dalam negeri, berorientasi pada ekspor dan memiliki keterkaitan kedepan dan kebelakang yang kuat. Pemerintah harus berusaha melindungi dan menjaga kelangsungan industri-industri yang berbasis teknologi rendah dan menengah namun mampu menyerap tenaga kerja dalam skala besar dengan cara menyediakan infrastruktur yang memadai agar bisa melakukan kegiatan proses produksi secara efisien yang pada akhirnya mampu meningkatkan daya saing dari subsektor ini.

\section{REFERENSI}

Badan Pusat Statistik. (2001). Statistik industri menengah dan besar Indonesia. Jakarta: BPS.

Banker, R.D., Charnes, A., \& Cooper, W.W. (1994). Some models for estimating technical and scale efficiencies in data envelopment analysis. Management Science 30 (9), 1079-1092.

Charnes, A., W.Cooper, \& E. Rhodes. (1978). Measuring the efficiency of decission making units, European Journal of Operational Research, 2, 429-444.

Farrell, M.J. (1957). The measurement of productive efficiency. Journal of the Royal Statistical Society 120 (series A), 253-281.

Giufrida, A. \& Gravelle, H. (2001). Measuring performance in primary care: Econometric analysis and DEA. Heslington York: Department of Economics and Related Studies University of York.

Insukindro, Nopirin, Makhfatih, A., \& Ciptono, S.M. (2000). Laporan akhir: Pengukuran efisiensi relatif pelayanan kantor cabang pegadaian. Yogyakarta: Penelitian dan Pengembangan Manajemen (PPM) Fakultas Ekonomi Universitas Gadjah Mada.

Jefferson, G.H. \& Xu, W. (1994), Assessing gains in efficient production among China's industrial enterprises. Economic Development and Culture Change, 3, 597-615.

Kost, F.E., \& Rosenwig, J.E. (1979). Organization and management: A system and contingency approach. United States: McGraw-Hill Inc.

Muchdie. (1998). Permodelan struktur ruang ekonomi Indonesia: Penerapan prosedur giriot untuk menyusun tabel input output daerah. Ekonomi dan Keuangan Indonesia, XLVI (3), 279-305.

Post, T. \& Spronk, J. (1999). Including economic uncertainty in data envelopment analysis: With an aplication of large european commercial banks. Finland: Helsinki School of Economics. 
Sobari, A. (2002). Disparitas efisiensi teknis antar sub-sektor dalam industri manufaktur di Indonesia (1988-1998), sebuah analisis makro penerapan metode DEA. Thesis. Universitas Gadjah Mada Yogyakarta: unpublished.

Walter, N. (1995). Microeconomic theory basic principles and extensions. Dreyden Press: New York. World Bank. (1994). Indonesia's environment and development, challenges for the future. Washington DC.

World Bank. (1997). Indonesia - Sustaining high growth with equity. Report no. 16433-IND. Washington, D.C., 30 May. 